Back to basics for high-energy physics

US panel's

ritual defence

\section{of accelerator}

\section{Washington}

The high-energy physics community in the United States is lifting only the littlest of fingers in defence of the proton-antiproton accelerator ISABELLE at the Brookhaven National Laboratory, Long Island. At a day-long meeting on Sunday, the influential High Energy Physics Advisory Committee accepted a subcommitee's recommendation that the accelerator should be completed only if there were a prior assurance of adequate support for research at the two other accelerator laboratories at Stanford, California, and Fermi National Accelerator Laboratory (Fermilab), Illinois.

ISABELLE may thus turn out to be the most conspicuous casualty of the new financial restraint. The physical infrastructure of the machine, a tunnel 2.5 miles in circumference, is 95 per cent complete. But something like a further $\$ 500$ million would have to be spent on magnets, vacuum systems and radio-frequency accelerating cavities if the accelerator was to be finished by 1990 .

If the project is abandoned, some 400 technical people at the Brookhaven Laboratory will be without jobs. There is even the gloomy possibility that, without its chief task, the survival of the laboratory itself will be in jeopardy.

The subcommittee report, the sole item on Sunday's agenda, had been prepared in less than three months by a group under $\mathrm{Dr}$ George Trilling of the University of California, Berkeley. The panel will go on to produce a more measured statement in January of the benefits that may derive from particle accelerators based on novel principles such as those being developed at Stanford and Cornell universities. This week's interim report was made necessary by the Department of Energy's need of an opinion from the high-energy physics community in advance of this week's crucial decisions within the Administration on how the latest 12 per cent budget cuts will be distributed.

Given the conflicting interests of its members, the panel's chief conclusion is understandably delphic. It "strongly recommends" that ISABELLE should be completed, goes on to argue that the tota! cost of high-energy physics to the Department of Energy would then be $\$ 440$ million a year and remarks that if this support is not forthcoming, the ISABELLE project cannot be continued.

At present, high-energy physics is

operating on a budget of $\$ 325$ million a year, at which level the principal accelerators cannot be operated full time for lack of funds with which to pay the electricity bills.

There is every sign that high-energy physics has reached a turning point in the United States. Three distinguishable constituencies have emerged - the operators of the accelerators at Fermilab and Stanford, who wish to see their equipment fully used, the adherents of ISABELLE, who argue that it is an essential tool for the $1990 \mathrm{~s}$, and the general university users of accelerators, who need more immediate access to existing machines but who recognize that without ISABELLE they will have even fewer experimental opportunities ten years from now. The interim report spells out the conditions that must be satisfied before funds are spent on the completion of ISABELLE:

- Full utilization of existing accelerators. - Completion of the Tevatron I accelerator upgrade for colliding 1,000 $\mathrm{GeV}$ protons and antiprotons based on existing Fermilab accelerators.

- A start on work on the Tevatron II

\title{
Top men resign in CNRS crisis
}

The two heads of the largest research agency in France - the Centre National de la Recherche Scientifique (CNRS) - fell last week in a self-delivered coup de grace.

On Wednesday, M. Jacques Ducuing, the director-general of CNRS, handed in his resignation to the minister for research and technology, M. Jean-Pierre Chevènement. Shortly after, the president of CNRS, Professor Charles Thibault who worked in tandem with Ducuing resigned also. He was followed by three of the six scientific members of the CNRS council, and the other three, including Louis Néel, a Nobel laureate representing the Academie de France, are likely to resign soon. (Néel, however, awaits the recommendation of the Académie.)

So what was the fuss? Chevènement was planning to wait until early next year before making any major changes at CNRS (and elsewhere) by which time he would have tested the water with the national colloquium on science and technology. The unions were unhappy with the CNRS directorate and had called for their resignation; but there was no sign of any movement yet.

Then, on Tuesday, after a long Socialist Party congress in which the party appeared to move to the left and chided the government for failing to confront the establishment more firmly, Chevenement decided he wanted to sack M. Christian Morrisson who was appointed director of social sciences at CNRS in April (before the general election).

Morrisson, it seems, was taking CNRS project, intended as the chief fixed-target accelerator for the 1980 s.

- Development of superconducting radio-frequency cavities (at Cornell University).

- Development of novel accelerator designs.

Much of Sunday's meeting was occupied with the cost of this minimal programme, eventually fixed at $\$ 395$ million a year: if ISABELLE were to be completed, the total high-energy physics budget of $\$ 440$ million a year would include an average of $\$ 80$ million a year for the construction of the machine. If, however, ISABELLE is abandoned, the committee argued, it would be necessary to spend an extra $\$ 35$ million on research and development on new accelerator technology.

The committee's optimism that its "minimal" programme may be funded derives from the agreement in 1979 between the Department of Energy and the Office of Management and Budget that high-energy physics could count on a budget of $\$ 300$ million a year, adjusted for inflation. Several members argued that even with the completion of ISABELLE,

social science in completely the opposite direction from Chevènement's own interests. The minister would like to expand social sciences in France, but in the direction of immediate public concern such as unemployment, or the changes implied by new technologies. Morrisson's interests were more academic.

So Chevènement called Ducuing and asked him if at the council meeting due the following day he would propose that Morrisson be replaced by someone more sympathetic - a M. Maurice Godelier, professor of anthropology at the Ecole des Hautes Etudes. Ducuing asked for more time to consult his colleagues but was refused. $\mathrm{He}$ resigned, and the other resignations followed, on the principle that the minister's insistence was an interference with scientists' responsibilities.

Chevènement, however, did not seem too disturbed by the events, despite the cries of some that the resignations would throw out of joint his whole plan for the reorganization of science and technology in France. At a press conference on Wednesday he asked journalists why they were so excited about the affair, pointing out that he had only proposed one change whereas in America the whole top administration was turned over at a change of government.

The minister now has a clear field on which to place his men, well before he had expected the opportunity. He is likely to be quick to make new appointments, though they must be approved by the council of ministers.

Robert Walgate 